\title{
STUDY OF HEMATOLOGICAL AND BLOOD BIOCHEMICAL PARAMETERS IN CATS EXPERIMENTALY INFECTED WITH TOXOCARA CATI
}

\author{
Al-NAQSHABENDY, A.A. \\ Department of Medicine and Surgery, College of Veterinary Medicine-University of Duhok-Iraq
}

Received: 10 December 2015; Accepted: 27 December 2015

\begin{abstract}
The present study was undertaken to assess and compare the hematology and serum biochemical parameters of cats experimentally infected with Toxocara cati (infected group) and healthy cats (control group). A total of fourteen and six blood samples were collected from infected and control groups respectively. Hematological changes showed a significant decrease of Hemoglobin concentration ( $\mathrm{Hb}$ ), Total Erythrocytes Count (TRBCs), Packed Cell Volume (PCV), and Platelets Count (Pt), furthermore a significant increase in Mean Corpuscular Volume (MCV) and significant decrease in Mean Corpuscular Hemoglobin Concentration (MCHC) which reflects a macrocytic hypochromic type of anemia is present. Results also revealed a significant increase in Total Leukocytes Count (TWBCs) due to significant increase of neutrophils and eosinophils. The results of serum biochemical parameters shown that glucose, Alanine aminotransferase (AST), Alkaline Phosphatase (AP), cholesterol and triglyceride significantly increased, whereas total protein and creatinine levels were significantly decreased in toxocara infected cats compared to healthy cats. But the serum bilirubin and Blood Urea Nitrogen (BUN) levels were not affected by toxocara infection.
\end{abstract}

Key words: Toxocara cati, blood parameters

\section{INTRODUCTION}

Toxocariasis is a public health problem and clinical syndrome caused by infection of zoonotic roundworms of cats (Toxocara cati) and dogs (Toxocara canis). Toxocara species are not only present worldwide in their definitive hosts only; they also frequently occur in other animal species and humans (In those so-called paratenic hosts) (Soulsby, 1986). T. cati is a common parasite of Felidae, and has a cosmopolitan distribution (Yamaguchi et al., 1996). Cats can become infected with $T$. cati by ingesting embryonated eggs found in contaminated soil or by predation of paratenic hosts - usually small rodents or birds containing live third-stage larvae (L3) in their tissues (Al-Quraishi, 2013). In pregnant queen, dormant tissue larvae are reactivated and migrate across the placenta to infect the fetus. New born kittens also acquire infection through ingestion of larvae in milk (Overgaauw, 1997).

Corresponding author: Dr. Al-NAQSHABENDY, A.A

E-mail address: asselvet2000@yahoo.com.

Present address: Department of Medicine and Surgery, College of Veterinary Medicine-University of Duhok-Iraq
The live cycle of $T$. cati is a complex, adult worm in the intestinal tract of infected cats shed large number of eggs into the environment; these may be ingested by final host as well as paratenic host. The larvas then hatch and migrate through blood vessels all over the body organs (Azizi et al., 2007). Those arrested larvae may lead to severe inflammatory reactions and consequently to a wide range of pathological and clinical manifestations, are possible causes of visceral larva migrants (VLM) or ocular larvae migrants (OLM) (Dubinsky, 1999).

The present study was taken into consideration to know the effect of toxocara cati infection on the hematology and blood biochemical parameters of experimentally infected cats.

\section{MATERIALS and METHODS}

The present study was carried out at the College of Veterinary Medicine, Duhok University, Kurdistan Region - Iraq. About $5 \mathrm{ml}$ of blood was collected aseptically from the cephalic vein of two groups of cats. The first group consist of 14 cats were experimentally infected with T.cati by ingested of embryonated infected eggs from previous work 
(Dishow, 2014) and the second group consist of 6 clinically normal cats which considered as a control group. The collected blood was stored in two separate tubes, one with anticoagulant EDTA for determine hematological parameters and another tubes without anticoagulant from which later serum was separated and it was put into a screw capped plastic vials, then stored at $-20 \mathrm{C}$ about one week for determine effects of T.cati infection on blood biochemical parameters.

The blood parameters determined by Auto hematology analyzer (model BC- 2800 vet, Germany), includes Total Erythrocytes Count (TRBCs), Packed Cell Volume (PCV), Hemoglobin concentration $(\mathrm{Hb})$, Platelets count $(\mathrm{Pt})$, Mean Corpuscular Volume (MCV), Mean Corpuscular Hemoglobin Concentration (MCHC). Furthermore total and differential leukocytes count was also encountered.

The serum biochemical parameters examined in the present study including glucose, Alanine Amino Transferase (ALT), Alkaline Phosphatase (AP), cholesterol, triglyceride, total protein, creatinine, bilirubin and Blood Urea Nitrogen (BUN) levels. All these parameters were done according to enzymatically measured using a standard enzymatic assay kit (Biolabo reagents, France).

Statistical analysis, the data of the present study were analyzed using unpaired ' $t$ ' test with accepted level of significant was $\mathrm{P}<0.05$ (Bowers, 2008).

\section{RESULTS}

The present study showed that the experimental toxocara infection in cats causes changes of hematological and serum biochemical parameters when compared with control group.

Hematology results revealed a significant decrease of $\mathrm{Hb}$, TRBCs, PCV, Pt, MCHC and a significant increase in $\mathrm{MCV}$ when compared with control group. According to these results showing that there is macrocytic hypochromic anemia in infected group. The results also give a significant increase in TLCs which were due to a significant increase of neutrophils, and eosinophils. While, the levels of lymphocytes, basophils and monocytes were not affected by toxocara infection, the results are seen in Table (1).

Table 1: Mean value of hematological parameters of the infected cats and control group.

\begin{tabular}{|c|c|c|c|}
\hline \multirow{2}{*}{$\begin{array}{l}\text { Serial } \\
\text { No. }\end{array}$} & \multirow[t]{2}{*}{ Hematology parameters } & \multicolumn{2}{|c|}{ Mean + Stander error of mean $(\mathrm{M}+\mathrm{SE})$} \\
\hline & & $\begin{array}{c}\text { Healthy cats }(n=6) \\
(\text { control group) }\end{array}$ & $\begin{array}{c}\text { Infected cats }(\mathrm{n}=14 \\
\quad \text { (infected group) }\end{array}$ \\
\hline 1. & Total RBCs X $10^{6} \mathrm{~mL}$ & $7.58 \pm 0.52$ & $4.24 \pm 0.13 \quad B$ \\
\hline 2. & $\mathrm{Hb}(\mathrm{g} / \mathrm{dl})$ & $15.95 \pm 0.60 \quad \mathrm{~A}$ & $5.86 \pm 0.27 \quad \mathrm{~B}$ \\
\hline 3. & $\operatorname{PCV}(\%)$ & $35.67 \pm 44.09 \quad \mathrm{~A}$ & $14.14 \pm 1.13 \mathrm{~B}$ \\
\hline 4. & $\operatorname{Pt} X 10^{3} \mu \mathrm{L}$ & $366.67 \pm 44.09 \mathrm{~A}$ & $146.43 \pm 7.76 \mathrm{~B}$ \\
\hline 5. & $\operatorname{MCV}(\mathrm{fl})$ & $42.75 \pm 2.60 \quad \mathrm{~B}$ & $55.86 \pm 1.37 \quad \mathrm{~A}$ \\
\hline 6. & $\operatorname{MCHC}(\mathrm{g} / 100 \mathrm{ml})$ & $33.20 \pm 0.46 \quad \mathrm{~A}$ & $25.21 \pm 1.13 \quad \mathrm{~B}$ \\
\hline 7. & Total WBCs X $10^{3} \mu \mathrm{L}$ & $14.50 \pm 0.81 \quad B$ & $21.86 \pm 0.75 \quad \mathrm{~A}$ \\
\hline 8. & Neutrophils $X 10^{3} \mu \mathrm{L}$ & $65.17 \pm 2.57 \quad \mathrm{~B}$ & $88.50 \pm 1.05 \mathrm{~A}$ \\
\hline 9. & Eosinophils X10 ${ }^{3} \mu \mathrm{L}$ & $0.60 \pm 0.34$ & $6.50 \pm 0.94 \quad A$ \\
\hline 10. & Lymphocytes $\mathrm{X} 10^{3} \mu \mathrm{L}$ & $21.83 \pm 2.75 \quad A$ & $25.00 \pm 1.94 \mathrm{~A}$ \\
\hline 11. & Monocytes $\mathrm{X} 10^{3} \mu \mathrm{L}$ & $3.17 \pm 1.56$ & $6.07 \pm 0.29$ \\
\hline 12. & Basophils $\mathrm{X} 10^{3} \mathrm{~mL}$ & $0.50 \pm 0.22$ & $0.64 \pm 0.29 \quad \mathrm{~A}$ \\
\hline
\end{tabular}

Different letters are significantly different at $\mathrm{P}<0.05$

In addition, the present study was carried out by employing various biochemical parameters to detect of the effects of T.cati infection on these parameters. The serum biochemical results were showed significant increase in glucose, alkaline phosphatase (AP), Alanine Amino Transferase (ALT), cholesterol and triglyceride levels. Results also indicated a significant decrease of total proteins and creatinine levels. Whereas, the serum bilirubin and BUN concentration were not affected by toxocara infection. The results of serum biochemical parameters are depicted in Table (2). 
Table 2: Mean value of serum biochemical components in infected and control group.

\begin{tabular}{|c|c|c|c|}
\hline \multirow[b]{2}{*}{$\begin{array}{l}\text { Serial } \\
\text { No. }\end{array}$} & \multirow[b]{2}{*}{ Serum biochemistry } & \multicolumn{2}{|c|}{ Mean + Stander error of mean $(\mathrm{M}+\mathrm{SE})$} \\
\hline & & $\begin{array}{l}\text { Healthy cats }(n=6) \\
\text { (control group) }\end{array}$ & $\begin{array}{c}\text { Infected cats }(n=14) \\
\text { (infected group) }\end{array}$ \\
\hline 1. & Glucose $(\mathrm{g} / \mathrm{dl})$ & $102.83 \pm 5.94 \mathrm{~B}$ & $229.23 \pm 14.74 \mathrm{~A}$ \\
\hline 2. & AP & $36.00 \pm 2.38 \quad \mathrm{~B}$ & $83.46 \pm 3.23$ \\
\hline 3. & ALT & $71.00 \pm 3.21 \quad \mathrm{~B}$ & $129.2 \pm 7.41$ \\
\hline 4. & Cholesterol (mg/dl) & $76.67 \pm 2.78 \quad \mathrm{~B}$ & $235.23 \pm 8.47 \quad \mathrm{~A}$ \\
\hline 5. & Triglyceride $(\mathrm{mg} / \mathrm{dl})$ & $48.33 \pm 10.46 \mathrm{~B}$ & $162.5 \pm 8.75$ \\
\hline 6. & Total proteins $(\mathrm{g} / \mathrm{dl})$ & $6.50 \pm 0.22$ & $1.69 \pm 0.21$ \\
\hline 7. & Creatinine $(\mathrm{mg} / \mathrm{dl})$ & $6.50 \pm 0.22$ & $0.77 \pm 0.07$ \\
\hline 8. & Bilirubin (mg/dl) & $0.43 \pm 0.08$ & $0.16 \pm 0.10$ \\
\hline 9. & BUN (mg/dl) & $21.17 \pm 0.54 \quad \mathrm{~A}$ & $21.08 \pm 0.24$ \\
\hline
\end{tabular}

Different letters are significantly different at $\mathrm{P}<0.05$

\section{DISCUSSION}

Hematological parameters recorded in this study revealed a significant decrease in $\mathrm{Hb}$, TRBCs, PCV, $\mathrm{Pt}$ and MCHC values with only increase in MCV value, that's reflecting macrocytic hypochromic anemia. Similar results were obtained by Bowman (1995) and Al-Obaidi (2012). All these variants may be due to response to migration of the toxocara larvae through different internal organs of cats which causes anemia due to internal bleeding (Dishow, 2014). Leukocytosis occurred in current study were also recorded by Bowman (1995) and Al-Obaidi (2012) which might occur due to stimulation of cellular immunity by specific antigenic structure of the toxocara larva and bone marrow as immune response against the parasite or their toxins (Dishow, 2014). Leukocytosis and eosinophilia may be attributed to immunological mechanisms, Coffman et al. (1993) showed the parasite - derived antigens stimulate Th0 cells to become Th2 cells, leading to the production of IL-4 and IL-5, which stimulate IgE production and eosinophils proliferation and maturation respectively. Leukocytosis and eosinophilia can occur in acute stage of toxocara infection (Sapunar and Ferdella, 1999).

In the current study, various serum biochemical parameters were recorded to evaluate the effect of toxocara infection. Most of them were found affected by the toxocara infection except bilirubin and BUN were not affected.

The blood glucose concentration in infected cats is increased significantly; this increase can be attributed to activation of glycogenolysis in liver due to migration of toxocara larva which causes anoxia, since liver glycogen is relatively unstable in the presence of a deficient oxygen supply (Coles, 1986). The results of the present study were in agreement with Vidal et al. (2003) who reported increase in glucose level due to toxocara infection.
There is elevation in serum enzyme activity as ALT due to malfunctioning of the liver, this observation is supported by other studies. Coles (1986) and Radostits et al. (2007) mentioned that the ALT and AST enzyme were increased due to disruption of hepatic cells as a result of necrosis or altered membrane permeability with visceral larva migrans. Especially, ALT enzyme is present in large quantities in the hepatocytes cytoplasm of these animal species (cats, dogs and primates) only, increased in serum when cellular degeneration or destruction occurs in liver (Coles, 1986).

Experimentally toxocara infection group had higher mean alkaline phosphatase (AP) levels when compared with control group and the difference was statistically significant. These results are in agreement with Azuma et al. (2002) who noted a case of hepatic involvement of visceral larva migrans due to toxocara causes increase AP enzyme level. AP enzyme also increased in biliary obstruction in cats or with increase corticosteroid (Coles, 1986).

Serum cholesterol and triglyceride levels are also significantly elevated with the rise of toxocara infection intensity could be due to the higher level of cortisol caused by stress of infection or due to hyperglycemic syndrome which associate with toxocariasis (Stockham and Scott, 2003).

There is a decrease in concentration of serum total protein and creatinine in the toxocara affected cats compared with control group may be due to liver damage and interference with proteins synthesis, not only due to larva migration, but also as a consequence of the development of oxidative stress (Azuma et al., 2002). In addition, the reduction in total protein value is might be due to alimentary tract dysfunction (diarrhea) or loss of appetite (Radostits et al., 2007).

In the present study, the serum bilirubin level does not get altered by toxocara infection. Our study is in agreement with Sapunar and Ferdella (1999) who revealed no change in serum bilirubin level in case of 
visceral larva migrans. Similarly, Sommerfelt et al. (2001) recorded no significant change in serum bilirubin in toxocara infected pigs.

In infected group with toxocara showed no significant change in their BUN, this result is in agreement with Singh et al. (1992) who observed no change in the level of BUN by toxocara infection in a case with visceral larva.

\section{REFERENCES}

Al-Quraishi, M.A. (2013): Study of histological and physiological effects of Toxocara cati larvae infection in experimentally infected white rats. International J. Current Microbiol. And App. Sci. 2 (8): 49-59.

Al-Obaidi, Q.T. (2012): Prevalence of internal helminthes in stray cats in Mosul city, MosulIraq. J. of Anim. and Vet. Adva. 11(15): 27322736.

Azizi, S.; Oryan, A.; Sadjjadi, S.M. and Zibaei, M. (2007): Histopathologic change and larval recovery of Toxocara cati in experimentally infected chickens. J. Parasitol. Res. 102: 4752.

Azuma, K.; Yashiro, N.; Kinoshita, T.; Yoshigi, J. and Ihara, N. (2002): Hepatic involvement of visceral larva migrans due to toxocara canis: A case report-CT and MR findings. Radiation Med. 20: 89-92.

Bowers, D. (2008): Medical statistical from scratch. $2^{\text {nd }}$ ed. Ed. by Wiely, J. and sons Ltd. Southern gat, UK. pp 187-201.

Bowman, D.D. (1995): Parasitology for veterinarians. $6^{\text {th }}$ ed. Ed. by Saunders, W.B.Co. USA. pp 203-319.

Coffman, R.L.; Lebman, D.A. and Rothman, P. (1993): Mechanism and regulation of immunoglobulin isotype switching. Adva. Immunol. 54: 229-270.

Coles, E.H. (1986): Veterinary clinical pathology. $4^{\text {th }}$ ed. by Saunders, W.B.Co. Philadelphia, London, Toronto.
Dishow, M.H. (2014): Prevalence of toxocariasis in dogs, cats and experimental infection in paratenic hosts and cats in Duhok province. MSc. Thesis. College of Vet. Med. Duhok University, Iraq.

Dubinsky, P. (1999): New approaches to control larval toxocariasis. Helminthol. 36: 159-165.

Overgaauw, P.A. (1997): Aspects of Toxocara epidemiology: human toxocarosis. Crit. Rev. Microbiol. 23: 215-231.

Radostits, O.M.; Gay, C.C.; Blood, D.C. and Hinchcliff, $K . W$. (2007): Veterinary medicine. A text book of the diseases of cattle, horse, sheep, pigs, and goats. 10th ed. W.S. Sannders Elsevier, London. pp 966-998.

Sapunar, J. and Ferdella, P. (1999): Larva migrante visceral toxocariasis cause eosinophilia and granulomas visceral. Bol. Parasitol. 54: 21-24.

Singh, S.A.; Malik, K. and Sharma, B.K. (1992): Visceral larva migrans in an adult. JAPI. 40: 198-206.

Sommerfelt, I.E.; Santillan, G.; Lopez, C. and Franco, A.J. (2001): Immunological and hematological response in experimental toxocara canis infected pigs. Vet. Parasitol. 96: 127-134.

Soulsby, E.J.L. (1986): Helminthes, arthropods and protozoa of domesticated animals. $7^{\text {th }}$ ed. Bailliere Tindall Publisher, Philadelphia, London. pp175-390.

Stockham, S.L. and Scott, M.A. (2003): Fundamental of veterinary clinical pathology. Iowa state press. USA pp 252-277.

Vidal, J.E.; Sztainbok, J. and Seguro, A.C. (2003): Eosinophilic meningoencephalitis due to toxocara canis: Case report and review of the literature. Am. J. Trop. Med. Hyg. 69: 341343.

Yamaguchi, N.; Macdonald, D.W.; Passanisi, V.D.; Harbour, A. and Hopper, C.D. (1996): Parasite prevalence in free-ranging farm cats, Felis silvestris catus. J. Epidemiol. Infect. 116: 217- 223.

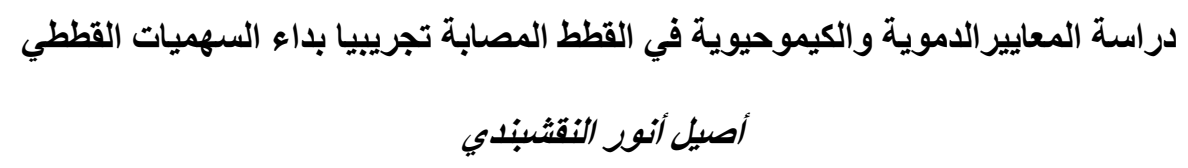

Email: asselvet2000@yahoo.com Assiut University web-site: www.aun.edu.eg

أستهدفت الدراسة إلحالية قياس ومقارنة التغيرات الدموية و الكيموحيوية في القطط المصابة تجريبيا بداء السهميات القططي (المجموعة المصابة)

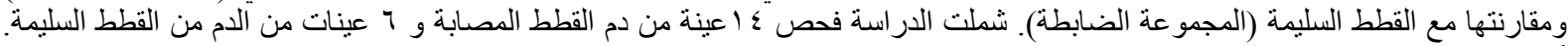

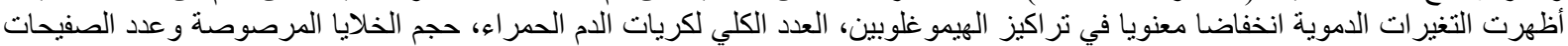

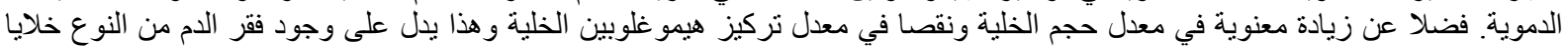

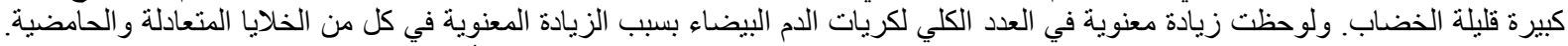

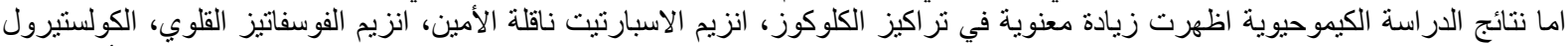

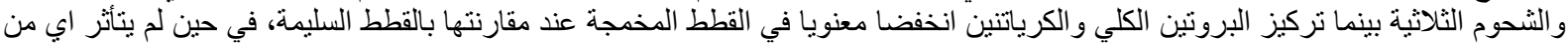

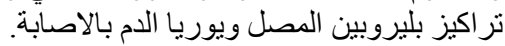

